\title{
ANOMALIAS AEROGAMAESPECTROMÉTRICAS (K, U E TH) DA QUADRÍCULA DE ARARAS-SP E SUAS RELAÇÕES COM PROCESSOS PEDOGENÉTICOS E FERTILIZANTES FOSFATADOS JOCELYN LOPES DE SOUZA
}

\author{
DISSERTAÇÃO DE MESTRADO - Programa de Pós-Graduação em Geologia - UFPR \\ DATA DE DEFESA: 23/10/98
}

\begin{abstract}
Fertilizantes químicos são utilizados em regiões tropicais, especialmente em áreas de grandes culturas, consideradas de abastecimento externo. Geralmente, radionuclídeos estão presentes nas matérias-primas utilizadas para a fabricação de alguns fertilizantes e, consequentemente, a redistribuição de urânio, tório e potássio, pela atividade agrícola, pode levar a contaminação dos solos intensivamente fertilizados. Dados aerogamaespectrométricos de $\mathrm{K}, \mathrm{U}$ e Th, provenientes do Projeto São Paulo/Rio de Janeiro, executado pela ENCAL S.A. para a CPRM, entre os anos de 1978-1979, mostraram na Quadrícula de Araras (SP), a coincidência entre anomalias aerogamaespectrométricas de $\mathrm{K}, \mathrm{U}$, Th e sills de diabásio. Esta área está localizada no estado de São Paulo, situada entre as coordenadas $22^{\circ} 00^{\prime} / 22^{\circ}$ $30^{\prime}$ de latitude sul e $47^{\circ} 00^{\prime} \mathrm{e} 47^{\circ} 30^{\prime}$ de longitude oeste. Como os teores de radionuclídeos em rochas básicas são baixos e, levantamentos aerogamaes-pectrométricos revelam a radiação gama, proveniente dos $30 \mathrm{~cm}$ da superfície do solo (coincidindo com a camada agricultável), despertou-se o interesse de investigar quais os solos inseridos nas referidas anomalias, bem como a atividade agrícola desenvolvida, para se averiguar se a fonte era oriunda dos fertilizantes químicos utilizados, conferindo assim o principal objetivo da presente pesquisa. $O$ geoprocessamento mostrou-se eficaz na integração dos dados multifonte como: geologia, solos, formações superficiais, drenagem, topográficos, de sensoriamento remoto, aerogamaes-pectro-métrico. Revelou que: as anomalias de $\mathrm{U}$ e Th ocorrem sobre Latossolos Roxos massivamente fertilizados com fosfatos, nas porções planas e elevadas do terreno; níveis elevados de urânio estão associados a granu-lometria argilosa em regolitos desenvolvidos sobre soleiras diabásicas; anomalias de potássio e tório acompanham os aluviões do Quaternário que percorrem as margens do Rio Moji, atribuindo-se às ocorrências de K anômalo, a presença de feldspatos nos solos inseridos e a ocorrência de Th associada à fertili-
\end{abstract}

zação local e ao transporte de argilas e óxidos de ferro provenientes das porções mais elevada do terreno, onde situam-se os Latossolos Roxos sob a cultura de canade-açúcar. Análises radioquímicas dos solos e fertilizantes revelaram a ocorrência destes radionuclídeos. Teores de urânio nos solos analisados mostraram-se superiores aos teores médios indicados pela literatura para solos ditos normais e superiores aos obtidos em pesquisa sobre acumulação de urânio, em solos há mais de oitenta anos fertilizados. As análises radioquímicas de $\mathrm{U}$ e Th em fertilizantes foram condizentes com a literatura, observando-se a influência da origem geológica da fonte da matéria-prima utilizada para a fabricação do fertilizante, bem como o aumento nas concentrações de urânio com o teor de P2O5 do fertilizante. Entretanto, estatisticamente, os resultados radioquímicos, não podem ser considerados representativos devido ao número reduzido de amostras não condizentes com o tamanho da área ( 278.865 ha) e acurácea do levantamento aerogamaespectrométrico onde está inserida a Quadrícula de Araras. Medidas gamaespectrométricas terrestres mostraram boas relações com as detecções aerogamaespectrométricas. As informações gamaespectrométricas aliadas as detecções de susceptibilidade magnética $(K)$ mostraram que o urânio e o tório tendem a se concentrar em solos oriundos do intemperismo de rochas básicas, mais desenvolvidos, argilosos e com K elevado. A retenção de urânio e tório em solos mais desenvolvidos e com predominância de argilas e óxidos de ferro, aliadas à informações de topografia, denotaram contagens gamaespectrométricas destes radionuclídeos maiores do que as encontradas em pedreira de diabásio. Maiores valores de $\mathrm{K}$ foram encontrados nos solos aluviais, devido a presença de feldspatos potássicos e micas nos minerais formadores destes solos, bem como pela lixiviação do potássio dos tratos mais elevados, e aqueles do embasamento cristalino, somadas a utilização de fertilizantes potássicos no cultivo de cana-de-açúcar. 